Sharif University of Technology
Scientia Iranica
Transactions E: Industrial Engineering
SCIENTIA

\title{
Development of supply chain strategy in the Iranian automotive industry based on system dynamics and game theory
}

\author{
S. Heidarzadeh*, A. Doniavi and M. Solimanpur \\ Department of Industrial Engineering, Urmia University, Urmia, Iran.
}

Received 8 November 2015; received in revised form 17 June 2016; accepted 27 September 2016

\section{KEYWORDS}

Supply chain;

System dynamics;

Game theory;

Shapley value.

\begin{abstract}
Supply chain is a system involved in moving a product or service from a supplier to a customer. Since the supply chain in a company includes all responsibilities and operations of the company, its design is necessarily a complete part of the strategic planning procedure of the company. This paper intends to develop a supply chain strategy through such tools as system dynamics and game theory. In this research, we have first identified the principal variables of the supply chain to draw the causal diagrams with feedback loops. Then, the layer and rate variables have been identified, layer and flow models created, and the simulation model implemented for 10 years by writing equations. To review the automotive industry, four main aspects have been selected for programming. The issue of selecting the best combination of strategy as a game with four players has been considered in which each player can select three strategies. Then, the Shapely Value has been used, and the influence of each player in creating desirability has been measured; the best strategy combination has been achieved by creating the decision tree. The results of this study show that automotive part makers will have the greatest impact on the future of the automotive industry in Iran.
\end{abstract}

(C) 2017 Sharif University of Technology. All rights reserved.

\section{Introduction}

Supply chain includes all activities to connect suppliers, raw materials, or services to the product or service manufacturers, and finally to the end-users [1]. Since the supply chain encompasses all the responsibilities and operations of the company, its design is necessarily a complete part of strategic planning procedure of the company [2]. For the majority of the companies, the objectives of strategic programming are similar

\footnotetext{
*. Corresponding author. Tel.:+98 $4432752741 ;$

Fax: +98 4432773591;

E-mail addresses: s.heidarzadeh@urmia.ac.ir (S.

Heidarzadeh); a.doniavi@urmia.ac.ir (A. Doniavi);

m.solimanpur@urmia.ac.ir (M. Solimanpur)
}

doi: $10.24200 /$ sci. 2017.4393 to or exactly the same as the those of supply chain management. Today, the variable market conditions together with diversified demands of the customers and intense competition between producers of goods and services necessitate the development of a supply chain strategy in line with reducing costs and quality approaches to survive under various conditions and to boost their efficiency [3]. During the recent years, determining the best strategy for the supply chain has become very important, but it has become difficult to address it and make easy decisions since the procedure is highly complicated and unstructured [1]. One of the important reasons for selecting the best strategy from various strategies is that the success of strategy in any company can be reflected in performance of that company, and the performance of the company can be a criterion for its success in the value generation 
of different parts of the market [4]. Therefore, the principal problem in this research work is selecting an appropriate strategy for the best efficiency in a supply chain.

Research review is done in two parts. The first part of research is related to the application of system dynamics and game theory in the supply chain. Ashayeri and Lemmes [5] developed a SD simulation for economic value added of a supply chain demand planning. Georgiadis et al. [6] used a system dynamics model for dynamic capacity planning of remanufacturing in closed-loop supply chains. Kumar and Yamaoka [7] performed a system dynamics study of the Japanese automotive industry closed-loop supply chain. Kamath and Roy [8] applied a SD framework for capacity augmentation of a supply chain for a short lifecycle product. Ozbayrak et al. [9] developed system dynamics modeling of a manufacturing supply chain system. Georgiadis and Besiou [10] studied sustainability in electrical and electronic equipment closedloop supply chains using SD approach. Fan et al. [11] presented a system dynamics modeling approach for a military weapon maintenance supply system. Kumar and Nigmatullin [12] extended Minegishi and Thiel [13] model to the details of perishable foods supply chain. Feng [14] used system dynamics modeling for supply chain information sharing. Tako and Robinson [15] investigated the application of discrete-event simulation and system dynamics in the logistics and supply chain context. Das and Dutta [16] used a system dynamics framework for integrated reverse supply chain with three-way recovery and product exchange policy. Khaji and Shafaei [17] used the dynamics of the system in order to simulate strategic partnership in the supply chain. The model presented by them includes the beginning of the supply chain (supplier) to deliver to a customer, manufacturer, and distributor. Sadeghi et al. [18] used the dynamics of the system to improve efficiency in the supply chain, such as production rates, inventory levels, and delayed orders in the supply chain of an electronic industry. Langroodi and Amiri [19] used the system dynamics approach in order to design a 5-level supply chain, including retailer, distributor of the final product, manufacturer, distributor of raw materials, and multi-product supplier. Saad et al. [20] discussed dynamic supply chain capabilities, and argued that system dynamics is capable of simulating various supply chains and that will come to light with the help of this simulation of the unknown consequences of the decisions. They stated that the major objective of this kind of simulation is acceleration and facilitation of learning about the behavior of systems under the present and future circumstances. Leng et al. [21] studied and classified the applications of game theories in supply chain management under competitive price and non-price factors. Zhao et al. [22] studied the coordination of supply chains retail and wholesale by option contracts through the cooperative game theory approach. Cachon and Netessine [23] worked on the concepts and applications of game theory in a supply chain analysis and classified the techniques into four groups of static non-cooperative, dynamic, cooperative, signaling, and Bayesian games. Tian et al. [24] developed a system dynamics model based on evolutionary game theory for green supply chain management diffusion among the Chinese manufacturers.

The second part of the research is related to the formulation of strategy in the supply chain. Chang and Ellinger [25] evaluated supply chain risk mitigation strategy and the relationship between risk management in supply chain and strategy development for risk mitigation in an organization. Perez et al. [26] worked on the development of lean strategy in the supply chain and applied a conceptual model as a tool for evaluation.

Using dynamic systems in studying the behavior of any phenomena, such as the process for development of supply chain strategy, will result in better acquisition and understanding of the factors influential in the success of business. Moreover, selecting an appropriate strategy faces certain problems. Therefore, in this research work, we will use a combination of system dynamics and game theory for selecting an appropriate strategy.

\section{Theoretical background}

\subsection{System dynamics}

Jay Forrester is the founder of system dynamics, which deals with the simulation of interactions between objects in dynamic systems [27]. Some experts believe that system dynamics refers to the fundamental concepts and basis for any type of systematic thought, but it is the pre-assumption of the majority of researchers that system dynamics is one of the existing approaches and tools to help people consider the consequences of the decisions and measures. In system dynamics, the resources are related to the physics or the constitution of the system, and they are the focus of attention of the transformation process that is happening in the system. The layers show the position and state of the system in any point. Even at the moments when the coefficient is at zero point, the layers will be still there. The layers are stocks that attract the changes in flows. The ratio variables, unlike the layer variables, will be zero in the case of stopping the system activity. Also, the flowchart represents the relations between ratio and layer variables in a model of system dynamics [28].

\subsection{Game theory}

Game theory, as a new branch of mathematics and a new approach to decision-making issues, has attracted 
the attention of many researchers in recent years. It is a branch of science that studies the decisions made by individuals in their interactions with others. In other words, game theory is the science of studying the conflict and cooperation between intelligent rational decision-makers. The major goal of game theory is presenting insight and viewpoint based on which the players must act rationally. A game comprises a number of players, collection of movements or strategies, and specific results for each combination of strategies. Generally speaking, game theory is classified as cooperative and non-cooperative games [29].

A game is cooperative if players are able to form binding commitments whose goal is to find a way for fair distribution of profit coming from cooperation. These games are usually studied in static form, and the functions of the utility of the players can be either fixed or expectational. A characteristic function form of $n$ person comparative game is an ordered pair of $G(N, V)$ where $N$ is a finite set of players $N=\{1,2, \ldots, n\}$ and $N$ is indeed the total number of players. The sub-set of $(S, S \subseteq N)$ is called coalition. For a cooperative $n$-person game, the Shapley value has calculated the average gain of each player from the coalition. This means that the amount of gain $u_{i}^{*}$ of player $i$ is specified by this concept. If player $i$ joins coalition $C$, his final productivity to the new coalition is defined as follows:

$$
\{V(C)-V(C-(i))\}
$$

Assuming that coalition has been formed in total from one to two or $n$ persons, and that there is any probability of joining the coalition, then $u_{i}^{*}$ belonging to player $I$ shows his final median productivity to the game as follows:

$$
u_{i}^{*}=\sum_{\substack{C \subset N \\ i \in c}} \frac{(K-1) !(N-K) !}{N !}\{V(C)-V(C-(i))\}
$$

so that:

$$
\begin{aligned}
& N \quad \text { total number of players, } \\
& C \quad \text { number of players in coalition } K, \\
& \frac{(K-1) !(N-K) !}{N !}=\text { probability of any new coalition. }
\end{aligned}
$$

Eq. (2) from the total calculations per each coalition may be gained from player $i$, and Shapley value $u_{i}^{*}$ can show the power and influence of player $i$ in winning a coalition. This power depends upon the increased productivity of a coalition after joining player $i$ to that coalition [30].

\section{The proposed framework for selecting optimal supply chain strategy}

The proposed framework for selecting the optimal strategy for automotive industry encompasses the following six steps:

- Step 1. Analyzing the industry under study: In this step, a general sketch of the industry and its status based on upstream documents, such as goals and policies of the industry development, is made;

- Step 2. Identifying the relationship between various layers of the supply chain: At this stage, the key elements in the supply chain are identified and defined by literature review, the study of published articles, and interview with the experts on this research topic;

- Step 3. Identifying cause-and-effect relationship: Based on the studies in the previous steps, a causeand-effect diagram is drawn and validated by the experts for cause-and-effect relationships;

- Step 4. Creating a flowchart based on the causeand-effect relationship in the supply chain: Based on the previous step and diagrams of cause-andeffect relationships, the layer and ratio variables are identified and model equations are written in Vensim software according to the history data, interview, and questionnaire;

- Step 5. Simulation and analysis of results as well as proposition of a strategy for improving supply chain performance: The previous step model is implemented and the results are analyzed. Also, the results are compared with the outlook plan and upstream documents, and various strategies are proposed in four areas;

- Step 6. Selecting the optimal strategy: Based on the results of simulation in the previous step, the issue of selecting the best strategy of an optimal combination of strategies is put forward in the form of a four-player cooperative game, and then the best strategy is selected based on shapely value.

\section{Formulating and selecting the optimal strategy for Iranian automotive industry}

Formulating and selecting optimal strategy for Iranian automotive industry encompasses the following six steps:

- Step 1. Analyzing the Iranian automotive industry: The Iranian automotive industry is comprised of two large corporations: Iran Khodro and SAIPA. The study of these two corporations can lead us to an evaluation of the automotive industry in Iran. The Iranian automotive industry has an outlook plan to 
attain the first rank in Middle East, fifth in Asia, and 11th in the world automotive industry through competitiveness based on technological development;

- Steps 2 and 3. Identifying the relationship among various layers of the supply chain, and cause-andeffect relationships: At this stage, the major elements of the supply chain and cause-and-effect relationships among them are identified through questionnaires and interviews with the experts as well as studying pertinent articles. The cause-andeffect diagram, including four major components of demand, production, sales and distribution, is drawn; a separate cause-and-effect diagram is made for each part, and finally four diagrams are made into a general cause-and-effect diagram, according to Figure 1;

- Step 4. Creating a flowchart based on the causeand-effect relationship in the supply chain: At this stage, the layer and ratio variables are identified and equations are made by Vensim software. The flow diagram is presented in Figure 2. To write the model's equations of historical data, time series, expert views, we used questionnaires and interviews as well as data gathering on automotive industry.

In this model, it is supposed that the entire demand is not translated into real demand. In other words, a percentage of the potential demands becomes practical. Customer satisfaction variable was used to specify what percent of the potential demands has become practical. Also, it was presumed that an automobile is made of six collections with six manufacturing sets, namely body and main parts, electrical and electronics, engine components and parts, suspension and steering systems, power transmission system, and miscellaneous auto parts. Also, it was presumed that the per capita income of each individual is influential in the demand for automobile. This is why gross national income is also included in the model. The model also pays attention to the import tariffs that have direct influence on the volume of imports per shortage of car in the market. The sales ratio for the domestic automakers was calculated based on three main parts. The first part is the percentage of potential demands that must be supplied by domestic production. The second part is the portion of delayed domestic production and a part of domestic production that there was no possibility for its production, so it is included under the lost order.

- Step 5. Simulation and analysis of results and proposition of a strategy for improving supply chain performance: The model has been implemented and used for 10 years. Results of the simulation show that per capita income increases with the rise in population and gross national income. With respect

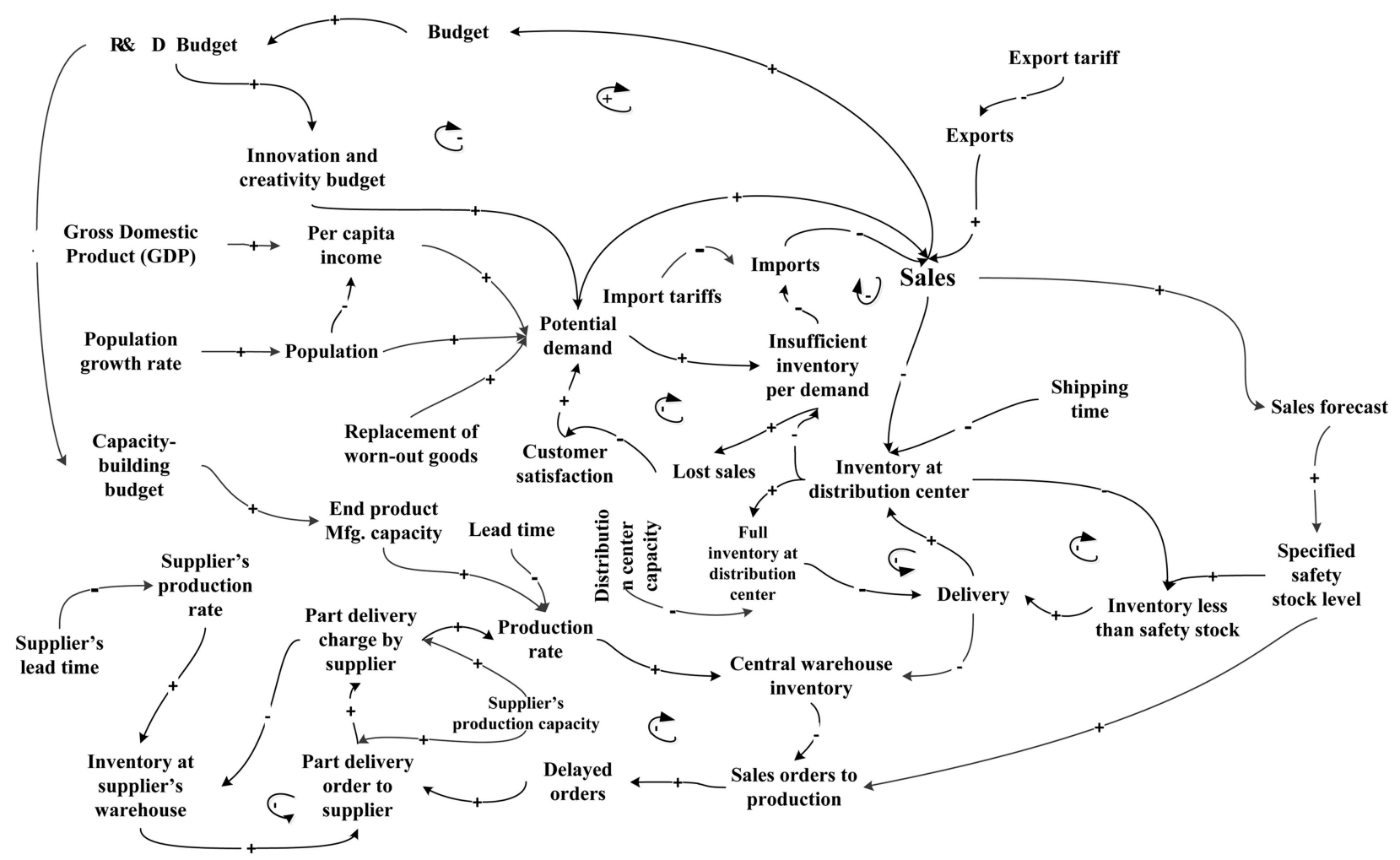

Figure 1. Cause-and-effect diagram of the Iranian automotive industry supply chain. 


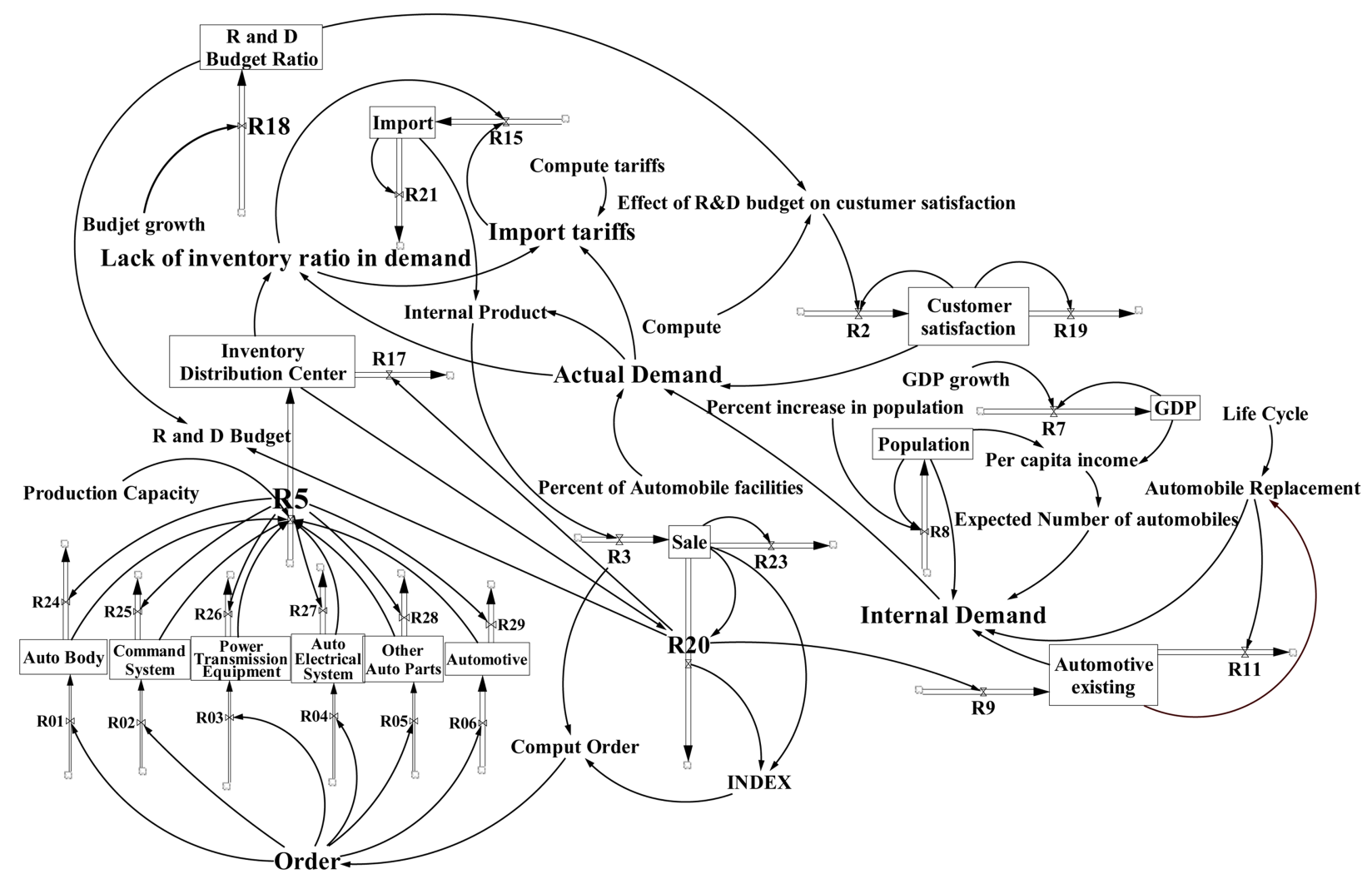

Figure 2. Flow diagram of the Iranian automotive industry supply chain.

to the capacity, production procedure, and average life expectancy of the Iranian cars that is above 15 years, at the beginning of simulation, the speed of replacement is more than that of production and this declines the number of vehicles. With the passage of time and putting behind the delays in production and replacement and renovation of the fleet, the number of the vehicles rises so that in the closing years of simulation, the average life expectancy is fixed at 15 years and this is the beginning for an increase in the number of vehicles. Also, according to the process, special to the replacement of the vehicles as well as annual changes in income, the demand was high at the beginning, but it became moderate in the closing years of simulation. Customer satisfaction changes according to the budget allocated to research and development $(\mathrm{R} \& \mathrm{D})$. At the beginning of simulation, the $\mathrm{R} \& \mathrm{D}$ budget constitutes a small portion of the budget; after the stipulated time, the ratio changes in favor of research and development and this gives a boost to customer satisfaction. Figures 3 to 5 depict the results of simulation model.

With respect to the results of simulation, the goals, mission, and the outlook plan of the Iranian automotive industry can be summarized in the following table in four already discussed aspects.

- Step 6. Selecting the optimal strategy by game theory: At this stage, the proposed strategies in Table 1 and all different combinations of the strategy derived from various aspects, according to Table 2, are simulated; the utility ratio (between 0 and 5) is allocated based on the results of simulation, their comparison to the outlook plan, and using expert views for each aspect (player). Then, the utility rates of the two-, three-, and four-person coalitions for each combination of strategy are calculated as in the following example:

$$
\begin{aligned}
& U F, C(F 1, C 1, I 2, L 2) \\
& \quad=U F(F 1, C 1, I 2, L 2)+U C(F 1, C 1, I 2, L 2) .
\end{aligned}
$$

Table 3 shows one of the possible three-person coalitions. Value characteristics, $V(C)$, of one coalition to normal form (two-dimensional) possess a saddle point based on Neumann-Morgenstern Utility Index. This is because the coalition members try to maximize their utility and non-members try to minimize their losses. Although the non-members may have positive gain under normal conditions, less income for the coalition members may have more gain for them. As $C_{\mathrm{ij}}$ shows utility of the coalition in raw $i$ and column $j$ of coalition $C$ matrix, so that raw $i$ indicates a combination of strategies of the coalition row $i$ and column $j$ indicates a combination of the strategies of 


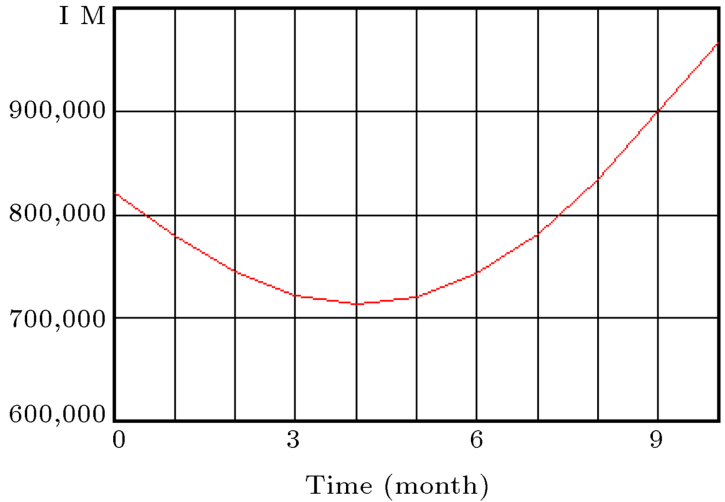

Automobile replacement: Current — number

(a)

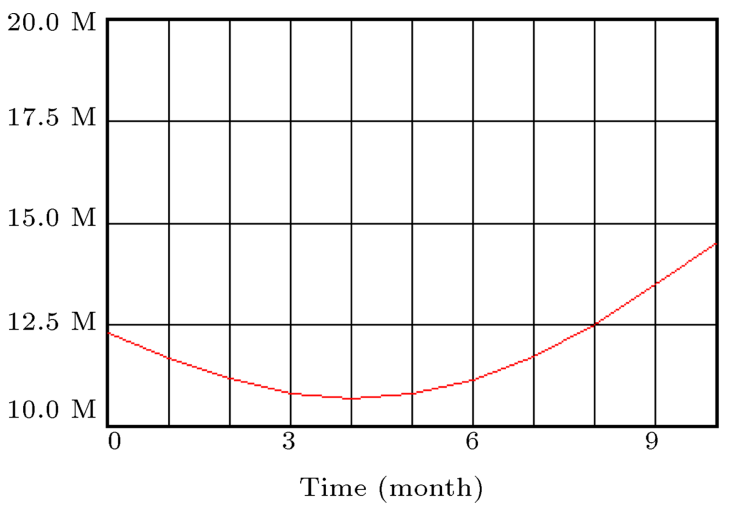

Automative exisiting: Current number

(b)

Figure 3. The result of simulation for the variables of the existing (a) automobiles replacement and (b) automotive replacements.

the non-members, and then $V(C)$ is extracted from solving the linear programming:

$$
V(C)=\max : Z
$$

ST :

$$
Z \leq \sum_{i} P_{i}^{*} C_{\mathrm{ij}} \rightarrow \forall j
$$$$
P_{i} \geq 0
$$

$$
Z: \text { Free }
$$

$P_{i}$ indicates the possibility of selection (from various combinations in raw $i$ ) for the coalition members. Now, in order to get the function of characteristics of various coalitions of diversified proposed aspects, linear programming Eq. (3) should be written based on coalition matrix, and $V(C)$ of any coalition should be solved by Lingo 11 software according to Table 4 .

The Shapley value of each player is attained by Eq. (2) per each player (aspect) according to Table 5.

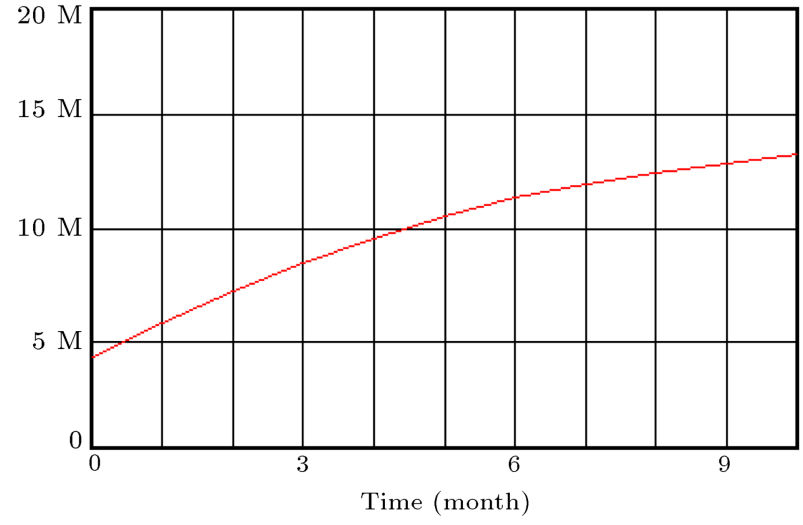

Internal demand: Current __ number

Figure 4. Results of simulation for internal demand variable.

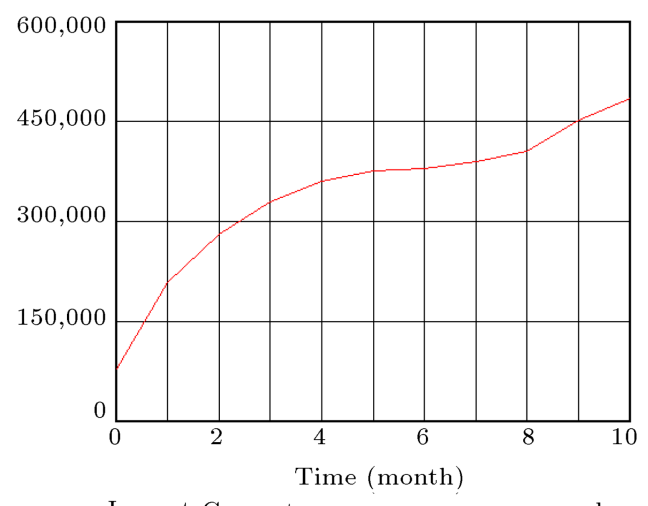

Import:Current

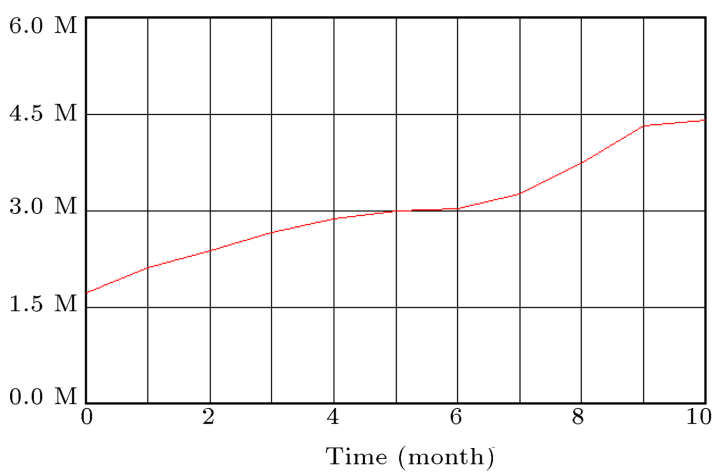

Lack of inventory ration in demand: Current — number

(b)

Figure 5. Result of simulation for variables of (a) import and (b) lack of inventory ration in demand.

With respect to the resulting Shapley value for the players, $C>L>I>F$ is the arrangement of power and a representation of their sensitivity to the coalitions. Therefore, in selecting strategy combination for implementation, the supplier aspect plays the decisive role, then with respect to the selection of the supplier aspect, the automaker aspect (distribution and sales), government aspect, and 
Table 1. The proposed strategies for improving vehicle performance of the supply chain.

\begin{tabular}{|c|c|c|}
\hline Proposed strategy & Code & Aspect \\
\hline $\begin{array}{c}\text { Investment in line with attracting modern technology and creating competitive } \\
\text { advantage through innovation in the product; } \\
\text { Gaining value added due to creativity in production; } \\
\text { Development of international cooperation in line with boosting production capacity. }\end{array}$ & $\begin{array}{l}\text { F1 } \\
\text { F2 } \\
\text { F3 }\end{array}$ & $\begin{array}{l}\text { Automakers } \\
\text { (production) }\end{array}$ \\
\hline $\begin{array}{l}\text { Development of systems for evaluation of the performance of suppliers; } \\
\text { Development of automotive parts and equipment export markets; } \\
\text { Joint venture with domestic automotive part and CKD makers with reputable trademark. }\end{array}$ & $\begin{array}{l}\mathrm{C} 1 \\
\mathrm{C} 2 \\
\mathrm{C} 3\end{array}$ & $\begin{array}{c}\text { Suppliers } \\
\text { (part makers) }\end{array}$ \\
\hline $\begin{array}{l}\text { Gradual reduction of import tariffs according to the automotive development industry; } \\
\text { Facilitating and reinforcing required infrastructures and legal grounds for export; } \\
\text { Renovation of transport fleet. }\end{array}$ & $\begin{array}{l}\text { I1 } \\
\text { I } 2 \\
\text { I3 }\end{array}$ & Government \\
\hline $\begin{array}{l}\text { Improving responsiveness to the customers, through development of distribution } \\
\text { networks and reducing delivery time; } \\
\text { Planning for increasing the number of automotive export markets; } \\
\text { Improving and developing after-sales services } \\
\text { in line with customer satisfaction. }\end{array}$ & L3 & $\begin{array}{l}\text { Automakers } \\
\text { (distribution, } \\
\text { sales, services, } \\
\text { after sale,...) }\end{array}$ \\
\hline
\end{tabular}

Table 2. Game structure cooperation in the supply chain with three strategies for each aspect.

\begin{tabular}{|c|c|c|c|c|c|c|c|c|c|c|}
\hline & & & $\begin{array}{r}\text { Game str } \\
\text { A }\end{array}$ & $\begin{array}{l}\text { lcture co } \\
\text { utomaker }\end{array}$ & $\begin{array}{l}\text { peration } \\
\text { aspect ( }\end{array}$ & $\begin{array}{l}\mathrm{n} \text { the sul } \\
\text { roductio }\end{array}$ & $\begin{array}{l}\text { ply chain } \\
\text { 1) }\end{array}$ & & & \\
\hline & & & & & & II & & & III & \\
\hline & & Gov*. I & Gov. I & Gov. I & Gov. I & Gov. I & Gov. I & Gov. I & Gov. I & Gov. I \\
\hline & & Sup**. I & Sup. II & Sup. III & Sup. I & Sup. II & Sup. III & Sup. I & Sup. II & Sup. III \\
\hline & & Gov. II & Gov. II & Gov. II & Gov. II & Gov. II & Gov. II & Gov. II & Gov. II & Gov. II \\
\hline & & Sup. I & Sup. II & Sup. III & Sup. I & Sup. II & Sup. III & Sup. I & Sup. II & Sup. III \\
\hline & & Gov. III & Gov. III & Gov. III & Gov. III & Gov. III & Gov. III & Gov. III & Gov. III & Gov. III \\
\hline & & Sup. I & Sup. II & Sup. III & Sup. I & Sup. II & Sup. III & Sup. I & Sup. II & Sup. III \\
\hline$\frac{0}{\tilde{\sigma}}$ & & Gov. I & Gov. I & Gov. I & Gov. I & Gov. I & Gov. I & Gov. I & Gov. I & Gov. I \\
\hline हี & & Sup. I & Sup. II & Sup. III & Sup. I & Sup. II & Sup. III & Sup. I & Sup. II & Sup. III \\
\hline$\frac{0}{2}$ & & Gov. II & Gov. II & Gov. II & Gov. II & Gov. II & Gov. II & Gov. II & Gov. II & Gov. II \\
\hline 菊 & & Sup. I & Sup. II & Sup. III & Sup. I & Sup. II & Sup. III & Sup. I & Sup. II & Sup. III \\
\hline 苞 & & Gov. III & Gov. III & Gov. III & Gov. III & Gov. III & Gov. III & Gov. III & Gov. III & Gov. III \\
\hline$\frac{2}{\sqrt{2}}$ & & Sup. I & Sup. II & Sup. III & Sup. I & Sup. II & Sup. III & Sup. I & Sup. II & Sup. III \\
\hline हี & & Gov. I & Gov. I & Gov. I & Gov. I & Gov. I & Gov. I & Gov. I & Gov. I & Gov. I \\
\hline$\stackrel{\Xi}{\Xi}$ & & Sup. I & Sup. II & Sup. III & Sup. I & Sup. II & Sup. III & Sup. I & Sup. II & Sup. III \\
\hline & & Gov. II & Gov. II & Gov. II & Gov. II & Gov. II & Gov. II & Gov. II & Gov. II & Gov. II \\
\hline & & Sup. I & Sup. II & Sup. III & Sup. I & Sup. II & Sup. III & Sup. I & Sup. II & Sup. III \\
\hline & & Gov. III & Gov. III & Gov. III & Gov. III & Gov. III & Gov. III & Gov. III & Gov. III & Gov. III \\
\hline & & Sup. I & Sup. II & Sup. III & Sup. I & Sup. II & Sup. III & Sup. I & Sup. II & Sup. III \\
\hline
\end{tabular}


Table 3. Utility normal form for coalitions $L, I$ and $F$.

\begin{tabular}{cccccc}
\hline & & $\boldsymbol{C}_{\boldsymbol{i}}$ & $\mathbf{1}$ & $\mathbf{2}$ & $\mathbf{3}$ \\
$\boldsymbol{F}_{\boldsymbol{i}}$ & $\boldsymbol{I}_{\boldsymbol{i}}$ & $\boldsymbol{L}_{\boldsymbol{i}}$ & & & \\
\hline $\mathbf{1}$ & $\mathbf{1}$ & $\mathbf{1}$ & 8 & 6 & 6 \\
$\mathbf{1}$ & $\mathbf{1}$ & $\mathbf{2}$ & 10 & 7 & 7 \\
$\mathbf{1}$ & $\mathbf{1}$ & $\mathbf{3}$ & 7 & 8 & 9 \\
$\mathbf{1}$ & $\mathbf{2}$ & $\mathbf{1}$ & 5 & 9 & 9 \\
$\mathbf{1}$ & $\mathbf{2}$ & $\mathbf{2}$ & 6 & 3 & 7 \\
$\mathbf{1}$ & $\mathbf{2}$ & $\mathbf{3}$ & 1 & 4 & 13 \\
$\mathbf{1}$ & $\mathbf{3}$ & $\mathbf{1}$ & 6 & 9 & 6 \\
$\mathbf{1}$ & $\mathbf{3}$ & $\mathbf{2}$ & 7 & 8 & 9 \\
$\mathbf{1}$ & $\mathbf{3}$ & $\mathbf{3}$ & 5 & 6 & 6 \\
$\mathbf{2}$ & $\mathbf{1}$ & $\mathbf{1}$ & 4 & 9 & 10 \\
$\mathbf{2}$ & $\mathbf{1}$ & $\mathbf{2}$ & 7 & 10 & 6 \\
$\mathbf{2}$ & $\mathbf{1}$ & $\mathbf{3}$ & 9 & 6 & 7 \\
$\mathbf{2}$ & $\mathbf{2}$ & $\mathbf{1}$ & 9 & 2 & 9 \\
$\mathbf{2}$ & $\mathbf{2}$ & $\mathbf{2}$ & 7 & 12 & 7 \\
$\mathbf{2}$ & $\mathbf{2}$ & $\mathbf{3}$ & 8 & 6 & 14 \\
$\mathbf{2}$ & $\mathbf{3}$ & $\mathbf{1}$ & 2 & 6 & 11 \\
$\mathbf{2}$ & $\mathbf{3}$ & $\mathbf{2}$ & 10 & 10 & 4 \\
$\mathbf{2}$ & $\mathbf{3}$ & $\mathbf{3}$ & 8 & 11 & 6 \\
$\mathbf{3}$ & $\mathbf{1}$ & $\mathbf{1}$ & 11 & 9 & 9 \\
$\mathbf{3}$ & $\mathbf{1}$ & $\mathbf{2}$ & 8 & 8 & 10 \\
$\mathbf{3}$ & $\mathbf{1}$ & $\mathbf{3}$ & 5 & 6 & 10 \\
$\mathbf{3}$ & $\mathbf{2}$ & $\mathbf{1}$ & 9 & 9 & 8 \\
$\mathbf{3}$ & $\mathbf{2}$ & $\mathbf{2}$ & 12 & 8 & 2 \\
$\mathbf{3}$ & $\mathbf{2}$ & $\mathbf{3}$ & 6 & 11 & 10 \\
$\mathbf{3}$ & $\mathbf{3}$ & $\mathbf{1}$ & 13 & 6 & 12 \\
$\mathbf{3}$ & $\mathbf{3}$ & $\mathbf{2}$ & 9 & 10 & 8 \\
$\mathbf{3}$ & $\mathbf{3}$ & $\mathbf{3}$ & 11 & 13 & 5 \\
\hline & & & & &
\end{tabular}

Table 4. Coalition function of characteristics.

\begin{tabular}{lc}
\hline Coalition function & $\boldsymbol{V}$ \\
\hline $\mathrm{V}(\mathrm{F})$ & 1.25 \\
$\mathrm{~V}(\mathrm{C})$ & 1.818182 \\
$\mathrm{~V}(\mathrm{I})$ & 1 \\
$\mathrm{~V}(\mathrm{~L})$ & 0.9 \\
$\mathrm{~V}(\mathrm{~F}, \mathrm{C})$ & 5.310345 \\
$\mathrm{~V}(\mathrm{~F}, \mathrm{I})$ & 5.57143 \\
$\mathrm{~V}(\mathrm{~F}, \mathrm{~L})$ & 5.44118 \\
$\mathrm{~V}(\mathrm{I}, \mathrm{L})$ & 5.251917 \\
$\mathrm{~V}(\mathrm{C}, \mathrm{L})$ & 5.516854 \\
$\mathrm{~V}(\mathrm{C}, \mathrm{I})$ & 5.5 \\
$\mathrm{~V}(\mathrm{~F}, \mathrm{C}, \mathrm{I})$ & 10.8636 \\
$\mathrm{~V}(\mathrm{~F}, \mathrm{C}, \mathrm{L})$ & 11.18182 \\
$\mathrm{~V}(\mathrm{~F}, \mathrm{I}, \mathrm{L})$ & 9.62857 \\
$\mathrm{~V}(\mathrm{C}, \mathrm{I}, \mathrm{L})$ & 12 \\
$\mathrm{~V}(\mathrm{~F}, \mathrm{C}, \mathrm{I}, \mathrm{L})$ & 19 \\
\hline
\end{tabular}

Table 5. Shapley value of players (aspects).

\begin{tabular}{cc}
\hline Player & Shapley value \\
\hline$F$ & 3.781 \\
$C$ & 5.377 \\
$I$ & 4.586 \\
$L$ & 4.639
\end{tabular}

finally automaker aspect (production) will respectively select a strategy for the best payoff.

\section{Conclusion}

The results of selecting the best strategy show that the first and foremost aspect in automotive industry for realizing the goals anticipated in the outlook plan is the supplier aspect (related to the automotive part makers).

The first strategy in this connection is the development of evaluation systems on the performance of the suppliers. The special condition of the Iranian economy in terms of automotive industry and rapid growth of this industry, on one hand and domestic rivalry and possibility of foreign rivalry, on the other hand, necessitate the need for evaluation of the performance of the manufacturers at competitive prices and quality and identification of their weaknesses. Therefore, it is doubly important to analyze their performance and find their weaknesses. The results of such evaluation will facilitate decision making on conditions of purchasing, granting loans, and presenting strategies for steering and promoting the manufacturers and boosting their credibility. This evaluation is made with an intention of paving the ground for constant improvisation and promotion of automotive part manufacturers in Iran. Therefore, it is necessary to develop the evaluation systems in automotive industry.

Another important strategy concerning the part makers is the development and expansion of the export markets. Since, during recent years, domestic automotive industry has outstandingly and swiftly promoted its automotive part design and manufacturing capabilities, the export of automotive parts to the international markets can be the first step for vehicle exports. With respect to the importance of non-oil exports in the Five-Year Development Plan, developing a long-term strategy for vehicle exports and exports of automotive parts in particular seems to be necessary.

Another important strategy is attracting direct foreign investment and joint venture with well-known branches in automotive part making. At present, the foreign investors have been chiefly involved in design, manufacturing, and producing mechanical and electronic parts. The Iranian automotive industry has been always yearning for direct foreign investment to develop its infrastructures. The ultimate interest of domestic automakers for the time being is inviting the foreign automakers to work in Iran to develop the Iranian automotive industry. Automakers are of the opinion that legal supports concerning foreign investment, especially in terms of financial and monetary initiatives along with growing demand for automobiles in Iran and the region, can turn Iran into a hub of standard vehicle manufacturing in the Middle East. 
The Islamic Republic of Iran has had efforts more or less towards the development of automotive industry, but its speed and quality has been low. A policymaking review of automotive industry in countries comparable to Iran can well justify the slow growth of this industry in Iran in comparison with such countries as South Korea.

The findings of this research show that one of the most important strategies for improvisation of the Iranian automotive industry is boosting engineering knowledge and product development in tandem with the world automotive industry with the capacity for marketing in world markets.

\section{References}

1. Fawcett, S.E., Ellram, L.M. and Ogden, J.A. Supply Chain Management: From Vision to Implementation, London: Pearson (2014).

2. Stadtler, H. "Supply chain management-an overview", In Supply Chain Management and Advanced Planning, pp. 9-36, Springer Berlin Heidelberg (2008).

3. Chopra, S. and Meindl, P. Supply Chain Managementm Strategy, Planning and Operation, pp. 265-275, Gabler (2007).

4. Wisner, J., Tan, K.C. and Leong, G. Principles of Supply Chain Management: a Balanced Approach, Cengage Learning (2015).

5. Ashayeri, J. and Lemmes, L. "Economic value added of supply chain demand planning: A system dynamics simulation", Robotics and Computer-Integrated Manufacturing, 22(5), pp. 550-556 (2006).

6. Georgiadis, P., Vlachos, D. and Iakovou, E. "A system dynamics modeling framework for the strategic supply chain management of food chains", Journal of Food Engineering, 70(3), pp. 351-364 (2005).

7. Kumar, S. and Yamaoka, T. " System dynamics study of the Japanese automotive industry closed loop supply chain", Journal of Manufacturing Technology Management, 18(2), pp. 115-138 (2007).

8. Kamath, N.B. and Roy, R. "Capacity augmentation of a supply chain for a short lifecycle product: A system dynamics framework", European Journal of Operational Research, 179(2), pp. 334-351 (2007).

9. Zbayrak, M., Papadopoulou, T.C. and Akgun, M. "Systems dynamics modelling of a manufacturing supply chain system", Simulation Modelling Practice and Theory, 15(10), pp. 1338-1355 (2007).

10. Georgiadis, P. and Besiou, M. "Sustainability in electrical and electronic equipment closed-loop supply chains: a system dynamics approach", Journal of Cleaner Production, 16(15), pp. 1665-1678 (2008).
11. Fan, C.Y., Fan, P.S. and Chang, P.C. "A system dynamics modeling approach for a military weapon maintenance supply system", International Journal of Production Economics, 128(2), pp. 457-469 (2010).

12. Kumar, S. and Nigmatullin, A. "A system dynamics analysis of food supply chains-Case study with nonperishable products", Simulation Modelling Practice and Theory, 19(10), pp. 2151-2168 (2011).

13. Minegishi, S. and Thiel, D. "System dynamics modeling and simulation of a particular food supply chain", Simulation Practice and Theory, 8(5), pp. 321-339 (2000).

14. Feng, Y. "System dynamics modeling for supply chain information sharing", Physics Procedia, 25, pp. 14631469 (2012).

15. Tako, A.A. and Robinson, S. "The application of discrete event simulation and system dynamics in the logistics and supply chain context", Decision Support Systems, 52(4), pp. 802-815 (2012).

16. Das, D. and Dutta, P. "A system dynamics framework for integrated reverse supply chain with three way recovery and product exchange policy", Computers and Industrial Engineering, 66(4), pp. 720-733 (2013).

17. Khaji, M.R. and Shafaei, R. "A system dynamics approach for strategic partnering in supply networks", International Journal of Computer Integrated Manufacturing, 24(2), pp. 106-125 (2011).

18. Sadeghiamirshahidi, N., Afshar, J., Firouzi, A.R. and Hassan, S.A.H.S. "Improving the efficiency of manufacturing supply chain using system dynamic simulation", Journal Teknologi, 69(2), pp. 117-119 (2014).

19. Langroodi, R.R.P. and Amiri, M. "A system dynamics modeling approach for a multi-level, multi-product, multi-region supply chain under demand uncertainty", Expert Systems with Applications, pp. 231-244 (2016).

20. Saad, S., Mohamed Udin, Z. and Hasnan, N. "Dynamic supply chain capabilities: A case study in oil and gas industry", International Journal of Supply Chain Management, 3(2), pp. 70-76 (2014).

21. Leng, M. and Parlar, M, "Game theoretic applications in supply chain management: a review", InforInformation Systems and Operational Research, 43(3), pp. 187-220 (2005).

22. Zhao, Y., Wang, S., Cheng, T.E., Yang, X. and Huang, Z. "Coordination of supply chains by option contracts: A cooperative game theory approach", European Journal of Operational Research, 207(2), pp. 668-675 (2010).

23. Cachon, G.P. and Netessine, S. "Game theory in supply chain analysis", In Handbook of Quantitative Supply Chain Analysis, pp. 13-65, Springer US (2004).

24. Tian, Y., Govindan, K. and Zhu, Q. "A system dynamics model based on evolutionary game theory for green 
supply chain management diffusion among Chinese manufacturers", Journal of Cleaner Production, 80, pp. 96-105 (2014).

25. Chang, W. and Ellinger, A., Evaluating Supply Chain Risk Mitigation Strategy, in Marketing Dynamism \& Sustainability, Springer International Publishing, pp. 594-595 (2015).

26. Perez, C., de Castro, R., Simons, D. and Gimenez, G, "Development of lean supply chains: a case study of the Catalan pork sector", Supply Chain Management: An International Journal, 15(1), pp. 55-68 (2010).

27. Forrester, J.W., The Beginning of System Dynamics. McKinsey Quarterly, pp. 4-17 (1995).

28. Coyle, R.G. System Dynamics Modelling: A Practical Approach, 1, CRC Press (1996).

29. Myerson, R.B, Game Theory. Harvard University Press (2013).

30. Watson, J. Strategy: An Introduction to Game Theory, 139, New York: WW Norton (2002).

\section{Biographies}

Somaieh Heidarzadeh received his MSc degree in Industrial Engineering from the Urmia University in 2015. His research interests are mainly in the area of supply chain management with special focus on supply chain strategy and system dynamics.

Ali Donivai is an Assistant Professor at Urmia University. He is the Head of Industrial Engineering Department. He has a $\mathrm{PhD}$ degree from Bath University and MS degree from Isfahan University of technology. His research interests are system engineering, product design, and manufacturing optimization. He has more than 70 journal and conferences papers.

Maqsood Soleymanpour is a Professor at Urmia University. He is the Vice Chancellor for Research and Technology Office at Urmia University. He has more than 100 journal and conferences papers. His research interests are system engineering, product design, and manufacturing optimization. 